
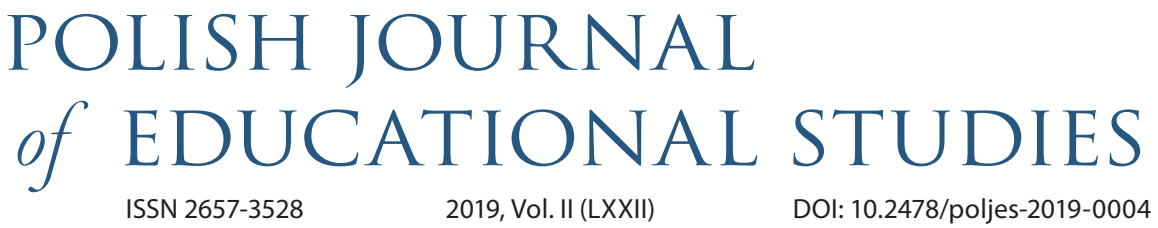

\title{
Language Taught to Students with Refugee Background Integration. The Context and the Importance of Developing Intercultural Communication Competence in School Education
}

\author{
Anna Młynarczuk-Sokołowska'
}

\begin{abstract}
The purpose of the article is to show the importance of developing intercultural communication competences in the use of the language of the host society among students with refugee backgrounds. The article begins with the presentation of the fundamental role of language. This research paper aims to analyse the relationship between culture and communication. The problems being presented revolve around the nature of the acculturation process and signal the connection between its successful course and the development of intercultural communication competences. The considerations undertaken in the text are illustrated by fragments of narrative from students with refugee migration experiences (from Chechnya and Ukraine) in the context of learning Polish in school education.
\end{abstract}

\section{KEYWORDS:}

intercultural communicational competence, acculturation, integration, education, students with refugee background

\section{Introduction}

The modern world is dynamically rushing forward, which creates many constructive possibilities, but on the other hand it forces people to live in conditions of permanent change and unpredictability. Nowadays, in many parts of the world, we can observe

1 Faculty of Education, University of Bialystok, Poland.

E-MAIL: a.mlynarczuk-sokolowska@uwb.edu.pl ORCID: 0000-0002-3355-0098 
a lack of political, state and social stability, as well as armed conflicts and wars, which imply social and economic stratification and a whole range of social problems. Currently, more and more people, motivated by various factors, are deciding to change their place of residence. The structure of each society, and the challenges and problems that they have to face are reflected in education. The space of modern Polish kindergartens and schools is becoming progressively diverse because of immigrants, re-emigrants and refugee students. ${ }^{2}$ Regardless of the reason for migration to Poland, foreigners "immerse themselves" in a distant reality, whose form is often determined by a complete difference from their own language and culture.

The purpose of this article is to present the importance of developing intercultural communication competences among students with refugee background. It focuses on the area of using the language of the host society. The paper begins with showing the nature and the importance of the language and its relationship to communication. Afterwards, the author undertakes the issue of developing intercultural communication competence in the course of acculturation as an integral element of learning new socio-cultural realities (knowledge of language and culture) and addresses issues regarding this integration. In this context, selected fragments of narratives, which constitute empirical exemplifications of the considerations made in the text, have been presented. In these extracts students who have experienced forced migrants describe their experiences related to learning the Polish language. ${ }^{3}$

2 The group of migrants consists of people leaving their country voluntarily, for whom the priority is to improve the economic situation or achieve professional promotion in a new country. And also individuals alone or with their families leaving their homeland for fear of losing health or life due to the situation in the country of origin (the problem of refugeeism). Re-emigrants are people who return from international migration.

3 The fragments of utterances of students with refugee background presented in the text were collected during the following research: Przestrzeń szkoły w percepcji uczniów z doświadczeniem migracji uchodźczej [Space of School in the Perception of Students with Refugee Background]. Realizator badania: Anna Młynarczuk-Sokołowska (2019). Formy i metody uczenia się języka polskiego dzieci cudzoziemskich wśród uczniów cudzoziemskich w wieku 7-12 lat. [Forms and Methods of Learning Polish by Foreign Students aged 7-12.] Research implementers: Anna Młynarczuk-Sokołowska, Katarzyna Szostak-Król (2014); Międzykulturowa kompetencja komunikacyjna w nauczaniu języka obcego dzieci w wieku 7-12 lat wśród lektorów języka polskiego jako obcego w szkołach podstawowych [Intercultural Communication Competence in Teaching a Foreign Language to Children aged 7-12 among Polish Language Teachers in Primary Schools]. Research implementers: Anna MłynarczukSokołowska, Katarzyna Szostak-Król (2014); Doświadczenia cudzoziemców dotyczace akulturacji w Polsce [Experiences of Foreigners Regarding Acculturation in Poland]. Research implementer: Anna Młynarczuk-Sokołowska (2017); Doświadczenia Polaków zwiq̨zane z akulturacja w wybranych krajach europejskich oraz migracja powrotna [Experiences of Poles related to Acculturation in selected European Countries and Return Migration] Research implementer: Anna Młynarczuk-Sokołowska (2017). 


\section{The fundamental nature of language}

The human world is a linguistic space. People are surrounded by language from the moment of conception to death. Language has a number of functions in human life. Thanks to the language symbol system, it is possible to express thoughts, views, ideas, etc. Language also allows us to acquire knowledge of the world (cognitive function). It is a tool for establishing and creating interpersonal relationships and the division of social roles (social function). Using language enables us to express emotions, both in everyday life and on a creative level (expressive function) (Kieklewicz, 2010, pp. 19-30).

Language has a social character - it is a product of a particular community that passes it on from generation to generation, and constantly shapes it. Lexical and grammatical structures, which are an integral part of every language, constitute a coded way of perceiving reality by a given group (e.g. a nation) that uses it. Language contains the content of its users' culture, experiences and wisdom of past generations, as well as stereotypes connected with various situations and social groups.

In the source literature, language is considered in different contexts. Depending on the scientific field (i.e. linguistics, cultural studies, sociology, etc.), particular aspects of the language are highlighted. Carole Logan and John Steward have presented ways of describing language which are important from the perspective of interpersonal relationships (including intercultural integration) and educational activities. These researchers of interpersonal communication, in reference to the content of the source literature, characterized language as a system of symbols and activities. In addition, using the metaphor of soup, they presented their own, slightly wider, way of understanding language (Stewart \& Logan, 2019, pp. 82-96).

According to the assumptions of the first approach (language as a system of symbols), language is composed of different types of words and grammar rules conditioning their combinations. In this connection, it is possible to speak of a given language as a system of symbols that enables the description of social reality and interpersonal communication. In the second approach (language as an activity), the emphasis is placed on the fact that a series of words are closely related to the action or act of doing something. For example, by saying the words "consider it a deal" - people make a contract. In this case, the words do not speak about the contract, but constitute its essential part. In the third view, language is described as a type of soup in which people swim - like fish in water. According to this approach, language is closely related to culture and perception. The language soup in which people live determines how they understand what they perceive, their thoughts and experiences. Cultures, definitions of social context and social roles are defined by the way of speaking. Therefore, a given culture conditions how to behave in various social situations, e.g. in a mature way, how to be a woman, a man, etc. (Stewart \& Logan, 2019, p. 82). 
In the context of what is written above, C. Logan and J. Steward, referring to the hypothesis of Edward Sapir and Benjamin Lee Whorf and the thoughts of Ludwik Wittgenstein, came up with wo conclusions associated with functioning in the language soup. The first one is connected with the fact that language and perception are interrelated. The second one indicates that the limits of a person's language are the boundaries of his or her world. This means that the grammar characteristic of a given language have an impact on the perception of the world, and the imagination and the actions of people who speak it (Whorf, 2011). By expanding the vocabulary, perception skills are deepened and the ability to talk with a larger group of people who have knowledge on various topics is developed. Thus, learning a foreign language allows us to learn how to think and perceive the world of a new community, because the vocabulary and grammatical structures of each language are a coded, autonomous way in which the world perceives its users. Some expressions within one language will never be the same as expressions from another one, due to the fact that they are embedded in different conceptual structures imposed on reality by given communicative communities (Maćkiewicz, 1999, p. 53).

Language enables communication, i.e. it is a symbolic process during which the negotiating and sharing of meanings occurs (Szopski, 2015, p. 15). Because of using language, it is possible to communicate with both, people from the "We" circle and representatives of different cultures belonging to the "They" circle. Communication with people of the same cultural affiliation has a similar character to intercultural communication, but the latter requires additional competences: communicative and intercultural.

\section{Culture and communication}

Edward T. Hall observed the inseparable relationship between culture and communication by saying that "communication is culture and culture is communication" (see more: Hall, 1987, 1997). Therefore, the way people communicate results from belonging to a specific culture, which is associated with the adoption of its characteristic language, principles and norms. Culture determines the ways of verbal and non-verbal communication and thus "reveals" itself during communication. A communication characteristic of a given culture is learned from an early age, largely in an unconscious way, by means of imitation. In this way, people acquire communication skills and learn to use them properly in their culture.

Contact with people belonging to different cultures creates a space for intercultural communication, which is a kind of meeting with a Stranger or an Other. Both the Stranger and the Other are characterized by a different cultural affiliation, which is associated with differences in perception of the world, values, lifestyle, etc. The way we perceive people belonging to various cultures in terms of Strangeness or Otherness depends on the level 
of knowledge of their culture and the emotions they arouse. The Stranger is a different (foreigner, member of a national or ethnic minority, etc.), unknown or little known person. He or she can therefore trigger negative emotions (Gudykunst \& Kim, 2019, pp. 448-449). Intercultural communication also takes place in contact with these Others, i.e. a person who, despite differences, is known and understood (e.g. family member, neighbor). Such people are perceived as predictable and non-threatening. The Other, unlike the Stranger, more often arouses curiosity, interest and the desire to make contact in order to get to know one another better. Intercultural communication makes it possible to learn about otherness and thus, enables the transformation from Strangeness to Otherness (Młynarczuk-Sokołowska, 2015).

It is worth noticing that in the course of intercultural communication, meanings are assigned to both words and gestures, because each communication process includes both verbal and non-verbal messages that are transmitted mutually and thus affect one another. Non-verbal messages are specific means of communication because they are usually expressed unconsciously. Thanks to the body language, people present themselves: their emotions, needs, views, etc. Vocalization (i.e. sound, tone of voice and other non-linguistic vocalizations e.g. pauses), kinesics (behavior based on movement), facial expressions, looks, proxemics (personal distances) and haptics (touch) - have a great impact on the course of interaction (Grove, 2019, pp. 122-123).

The culture in which people live largely manifests itself in a non-verbal way and it provides a great amount of information. Thanks to the analysis and interpretation of non-verbal messages, it is possible to read many norms, values and cultural principles. For example, by observing members of a particular national or ethnic group, it is possible to observe attitudes towards older people, perceptions of time, female and male roles, etc. Geert Hofstede, defining culture as "collective mind software that distinguishes members of one group from another" (Hofstede, Hofstede \& Minkov, 2010). This definition draws attention to unconscious way of expressing itself. ${ }^{4} \mathrm{He}$ claims that this software works automatically, outside consciousness. In the case of a meeting with the Stranger or the Other, when people do not have intercultural competence, they will probably behave in accordance with their own "cultural software", doing it unconsciously. In the process of intercultural communication, it is necessary to go beyond the ethnocentric point of view, according to which the Stranger and/ or the Other is perceived as "worse, deviating from the norm" adopted by the culture to

4 Geert Hofstede has identified five dimensions of national cultures based on empirical research: power distance, hierarchy (degree of hierarchy of countries, multiple levels and distribution of power); individualism-collectivism (a type of social structure and interpersonal relationships, the role of the group and the scope of expectations towards it); masculinity-femininity (gender in society, division of roles, tasks); avoidance of uncertainty (degree of avoidance of unclear situations, creation of norms, social contracts and scope of their respect); distant-close time orientation (basing making decisions on tradition, past or present and future) (see: Hofstede, Hofstede, \& Minkov 2010). 
which the individual belongs. This is connected with convictions about the superiority of the culture of one's own group and treating the rules, norms and values which are set by it as "right" and all others as "wrong". The tendency to judge Strangers and Others according to one's own cultural standards is natural, but hinders contact with Them (Gudykunst \& Kim, p. 497). Intercultural communication becomes effective when we adopt an attitude closer to cultural relativism, which makes it possible to interpret the behaviour of people of different cultural affiliations in the context of their culture. Then different cultural features are not considered in the categories of "good/bad" and evaluated. They are seen simply as different (Gudykunst \& Kim, p. 497).

Communication with Strangers and Others requires knowledge of how to interact with the partner's language and culture. Sławomir Magala notes that fluent use of a foreign language "only improves the verbal channel of social interaction and intercultural communication" (Magala, 2011, p. 45). This is an important skill, but not sufficient in the process of intercultural communication. In order to effectively communicate with Strangers and/or Others, it is necessary to "break the culture code", which involves the ability to recognize context and interpret ambiguity (p. 42). Thanks to breaking the code of a given culture, people should be able to generate creative statements and perform actions accepted in social situations that they have never encountered before. According to the researcher, effective communication with Strangers and Others, apart from communicative competence, requires also intercultural competence, which can be compared to a backpack or a set of tools independently completed by people, if they have to deal with different cultural software in one place (p. 40).

In the context of what is written above, it is worth emphasizing that while preparing people with migration experience to live in a different socio-cultural reality, we need to highlight the need to form intercultural communication competence, which assumes a close relationship between language and culture. Intercultural communication competence presupposes knowledge of the realities of life in a given country and its cultural specificity. Its development is currently an important goal of teaching foreign languages to foreigners (Aleksandrowicz-Pędich, 2005; Bandura 2007) ${ }^{5}$ and thus of European educational policy. ${ }^{6}$

5 Extending the concept of communicative competence with an intercultural element is the subject of many publications (e.g. Aleksandrowicz-Pędich, 2005; Bandura, 2007).

6 See among others Common European Framework of Reference for Languages: Learning, teaching, assessment. (2001). Strasburg. Council of Europe: Cambridge University Press. Common European Framework of Reference for Languages is a document developed by experts of the Council of Europe, which has gained the importance of an international document. Didactics refer to its content while creating curricula, textbooks etc. for the purposes of language education. The provisions contained in the document result from the recommendations of the Committee of Ministers of the Council of Europe regarding the improvement of the quality of language education in pursuit of achieving better communication among Europeans with different languages and cultures. 


\section{Language in the acculturation process}

The process of entering a different culture (acculturation) is long-standing and covers various spheres of human functioning. Acculturation is associated with gradual adaptation to the culture of the language learned by a foreigner without having to give up a relationship with the native language and culture (Acton \& Walker de Felix, 1986; Polok, 2006).

Acculturation can take many forms and bring many results, changing the system of values, range of behaviours and thus identity. Source literature distinguishes a number of strategies for individual and group adaptation to cultural systems. According to psychologist John W. Berry, the process may end up with integration, assimilation, separation, or marginalization (see more: Berry, 1998, 2003, 2006).

The optimal strategy of acculturation from the point of view of mental health and opportunities for balanced functioning in a new country is integration, which is expressed by maintaining one's own culture and having contact with the new one at the same time (Berry, 1998). Integration is a factor which enables an individual to feel that the way he or she assimilates a new culture allows them to eliminate the tensions arising from the differences between them and their own group and the new environment. Integration can be expressed through the attitude of unification of both cultural systems, taking the form of syncretism, resulting from egocentrism, where only elements that in some way seem to be convenient are borrowed from a different culture; or syncretism, correlated with an open attitude, where the individual is looking for a synthesis of both cultural systems in which it becomes possible to maintain the coherence of the cultural elements incorporated into it (Berry, 2006).

Acculturation is an active process. It does not rely on mechanical acceptance of ready-made elements or content of a foreign (dominant) culture, but on their specific processing based on native (dominated) culture. As a result, it gives a new cultural quality (Wysocka, 2003). This means that a well-integrated "foreigner" has adopted the behavioural norms which are characteristic of the host country's culture and knows which to apply in a given context so that his or her behaviour is accepted by native speakers of the language and culture of the country.

We need to remember that a person is able to adopt various strategies in different spheres of life, as well as change them during the acculturation process. For example, the initially manifested separation in peer relationships, (e.g. when making new friends) can turn into integration. The acquisition of intercultural communication competence is a priority for the favorable course of the acculturation process. This involves learning a dominant language spoken by the host society and acquiring the ability to cope with cultural difference. Lack or poor knowledge of the language used in the new country of residence prevents integration, and may even be a cause of separation, 
marginalization and social exclusion. Without acquiring intercultural communication competence, it is unrealistic to find oneself in a new class, school or a peer group.

Language is a product of a specific community. It cannot exist apart from the group that uses it and shapes it at the same time. It is not possible to think without the help of a language, hence everyone who learns a new language, learns the way of thinking of another community, discovers a different world, an unknown reality. It can be stated that it "broadens its horizons", enriches its worldview, because the vocabulary and grammatical structures of each language are an encoded autonomous way in which the world is perceived by its users (Mańczyk, 1982, pp. 44-45).

The newly learned language system becomes for its user both an indispensable tool of interpersonal communication, during which, in a verbal and non-verbal way, the content of culture manifests itself, as well as an interpretation tool of the surrounding reality that enables understanding of the perception of the world from the perspective of members of a given group. It is a factor in learning about and incorporating elements of a new culture into one's own cultural system, as well as fully-fledged functioning in a new society and thus the formation of double, open identities.

\section{School as a space to learn a new language. Towards intercultural communication competence?}

School is an autobiographical place. It means that at school, regardless of their nationality, social status or religion, students gather a number of experiences which are extremely important from the perspective of psychological and social functioning. These experiences often influence the future life choices of individuals. In the case of students from a forced migrant environment, the school plays an important role from the perspective of the integration process. Its success depends largely the on support in learning a new language, taking into account knowledge of new socio-cultural realities. Systematically developed communication competences (in the intercultural context) enable not only the prevention of school difficulties, but also build studentpeer-teacher relationships and full participation in the life of the class and school community (Młynarczuk-Sokołowska \& Szostak-Król, 2019).

Currently, in the process of teaching students with migration experience (including students with refugee background) a new language, the need to apply an intercultural communication approach is emphasized. According to its assumptions, language ceases to be just a dead subject of teaching grammar structures, and becomes

7 Statments of students with refugee background included in this part of text were linguistically corrected. 
a broadly understood communication tool for analyzing the world, which structures consist of culturally established and ordered forms and categories (Zawadzka, 2000; Gębal, 2010, 2017; Młynarczuk-Sokołowska \& Szostak-Król, 2016). Development in accordance with the intercultural approach - intercultural communication competence - enables gradual learning about new linguistic and cultural realities. That is why the cultural context is so important while undertaking any language activities that accompany establishing and maintaining communication. Culture determines the ways of verbal and non-verbal communication. The development of intercultural communication competence successfully affects the process of acculturation, which is the desirable effect of integration.

Polish law allows access to the universal education system for every child staying in the country - regardless of nationality or legal status. ${ }^{8}$ At present, in Poland, for children and young people from the age of 7 education is compulsory, which obliges them to study in an eight-grade primary school, but only until the student becomes 18 years of age. ${ }^{9}$ According to the Polish law, it is possible to support students with migration experience by studying in preparatory groups (welcome class), cooperation with an assistant teacher (intercultural assistant), organizing classes in Polish as a foreign language, leveling school backlogs, developing their cultural identity and religion. ${ }^{10}$

The most numerous group of students with refugee background in Poland are people from Ukraine (including the Crimean Tatars) and Chechnya." Usually, students

8 Art. 70 of the Polish Constitution of April 2, 1997 is a guarantee of participation in education regardless of nationality and legal status. In addition, the basics of free education of foreigners and taking actions to integrate in the education process are regulated by the provisions of the Act of December 16, 2016 on Educational Law and the Regulation of the Minister of National Education of August 23, 2017 on the education of people who are not Polish citizens and the ones who are and received education in schools functioning in the education systems of other countries.

9 See more: Act of December 14, 2016, Educational Law.

10 See more: Regulation of the Minister of National Education of August 23, 2017 on the education of people who are not Polish citizens and the ones who are and received education in schools functioning in the education systems of other countries.

11 In recent years, the nature of refugee migration in Poland has changed significantly (countries of origin of refugees, students functioning at schools, society, etc.). The largest group of foreigners covered by international protection in 2017-2018 were Ukrainians. According to the annual report of the Office for Foreigners in 2018 regarding the implementation of the obligations of the Republic of Poland resulting from Geneva Convention relating to the Status of Refugees and the New York Protocol regarding the Refugee Status) applications for international protection were filed in Poland by 4,1 thousand foreigners (on average one application included 2 or 3 people). Most of them ( 2.7 thousand applications), have been submitted by the Chechens. According to the opinion of the Office for Foreigners, the conditions for granting one of the forms of international protection were met by a total of 406 people (protection was granted to all families). They were mainly citizens of Ukraine (including Crimean Tatars) (95 people). 79 citizens of Russia, mainly Chechen nationality, received international protection. In the third place were citizens of Iraq - 27 people. In addition, 212 foreigners received permission for tolerated stay or for humanitarian reasons (the so-called national protection). In previous years Chechens were the ones who received such permissions. 
with a refugee background start learning at Polish school "from day to day" - without prior preparation. Thus, they rapidly "collide" with the new language, teachers, peer group, etc.

(...) We came first to the border, we sat there for two or three hours, later the bus took us to a center for foreigners. We came to a center for foreigners. We've been there for two months. Then we went to my mum and dad's friends. They have got a lot of Polish and Ukrainian friends. We were in the village for a week. And later dad comes and says "okay - you are going to school tomorrow" - and we - "ooo ... - we still don't know Polish ...". We come ... and in Ukraine I was still in fourth grade... And this one - I come - and everyone looks at me. And I sit down. And then the teacher asks me - "what is your name?" And I don't know what to say... And later she began to speak Russian - "ooo... she knows my language" - I thought. Okay, we can talk. And I started talking - and everyone laughs - I don't know Polish. And then I learned for about two days, three days. And later the headmaster said - you will go to the third grade - you don't know Polish, you have to learn. I - "Ok, I will learn and see what will be next". And I went to the third grade. And I liked it there (...). (Muslim, 13 years old, Ukraine) (Research: Przestrzeń...).

Beginning education in a new country of residence requires from students adaptation to new realities, which often differ in many areas (e.g. school functioning, student-teacher relations) from those in the country of their origin. The new school often sets different requirements for foreigners. Differences related to functioning in a various socio-cultural and linguistic realities, cultural affiliations different from most students, different from previous school programs and existing bonds in a given class community mean that for students with a refugee background it is not easy to "enter" a new school reality (Młynarczuk-Sokołowska, 2017).

It happens that students with refugee backgrounds, at the beginning of their stay in Poland, experience so-called culture shock (Barzykowski, Grzymała-Moszczyńska, Dzida et al., 2013). Culture shock is greatest the bigger the differences between the culture and native language of refugees and the dominant culture and official language of the new country are. Pupils from Chechnya find it much more difficult to find themselves in Polish socio-cultural realities than Ukrainians or Crimean Tatars. ${ }^{12}$ Referring to the content of the concept of national cultural dimensions by G. Hofstede (Hofstede, Hofstede \& Minkov, 2010) on which cultural differences are embedded, it can be stated that this happens, among others because the culture of Chechens (Caucasian people who profess Sunni Islam) is much more different from Polish culture (masculinity - femininity, power distance, time orientation) than for Ukrainian or

12 In this part of the text, the author refers to her own experiences connected with working for a long time with refugees in school as an intercultural adviser, in a foreigners' center in Bialystok and the Dialog Foundation. 
Crimean Tatars. The languages spoken by Chechen students (Chechen, Russian) also differ more significantly from Polish rather than Ukrainian.

It is easier for both students and teachers to interpret better the behavior of Ukrainians and Crimean Tatars than Chechens, which often turns into mutual relationships. The low level of teachers and students' knowledge about cultural differences between Polish and Chechen culture often leads to the use of negative stereotypes, attributing to Chechens and/or their behavior wrong intentions, misunderstandings and conflicts. Poor knowledge of Polish by students with refugee background is not only a barrier for learning, but also in terms of self-expression, solving peer conflicts, etc.

(...) We arrived in January and I have birthday in January. I was exactly 7 years old when I came to Poland (...). The beginnings were not easy (...) for example my peers at school were calling me names. I could not argue my stay in Poland because I did not know Polish so well. Due to the lack of knowledge of Polish language, I had difficulties with studying in primary school, but over time this problem passed when my peers learned that I was no different from them and I am the same person as them (...). (Bersan, 18 years old, Chechnya) (Research: Doświadczenia...).

An additional difficulty in the process of language learning, mastering the content of education and integration with the class community is often a multiple change of residence, which is also not conducive to the feeling of psychological stability and creating a class community (Barzykowski, Grzymała-Moszczyńska, Dzida, et. al., 2013).

I am from Chechnya. I came from Germany. First I lived in Chechnya. As my birthday was approaching - four years ago - I came to Poland. I have lived in the center for eight months. Then we received a stay. We lived in a rented apartment. I went to school No. 15 and 19. Then we went to the Netherlands. From there, I don't know where - because I was little - I think it's Germany. I have studied there for three months. And I didn't speak German well ... I didn't speak well... When I came to Poland and met my friends, I started to speak Polish. Then I started talking better and I was meeting with my friends. And in Germany I only had one friend. She was a Tatar. girl She couldn't speak Russian - only German - because she has lived there since she was a child. (Hvra, 15 years old, Chechnya) (Research: Przestrzeń...).

Empirical research ${ }^{13}$ and observations of the author of the text related to many years of work with students with refugee background ${ }^{14}$ indicate that the school is the basic environment in which these children learn Polish. Due to school attendance, refugee students are immersed in this language soup on a daily basis (Stewart \& Logan, 2019, pp. 82-96). Participation in lessons, extracurricular activities and other forms of

13 See bibiography: section empirical material.

14 See note no. 12. 
education, implemented through various forms of work, even force the use of a new language.

I study Polish at school during lessons and additional classes. Our class teacher teaches us. We read and do exercises from the book - but we mostly speak in Polish - and we also read. We talk as well - someone asks and you answer. We also draw things and read books, and we learn this way. For example, we drew mosques. We also did the dictation exercise. We also watch movies. For example, we watched a movie about how Poles lived in the past (...). (Ashab, 10 years old, Chechnya) (Research: Formy...).

Polish school, with the help of implemented educational programs, is also the main entity that introduces people from migrant environments into the world of Polish culture. During the school year, students learn about Polish legends, traditions (related to the celebration of national and religious holidays), songs, national symbols, etc. For example, on the first day of spring, they create with peers a traditional "marzanna", 15 on Fat Thursday ${ }^{16}$ they taste donuts and in this context they learn what this custom symbolizes. Around Christmas, they have the opportunity to prepare Christmas cards and Christmas decorations.

Despite the fact that Polish school plays a key role in the process of preparing for life in new cultural realities, it rarely includes the cultural affiliation of students with migration experience in the educational process. The programs of Polish schools are largely monocultural in nature, focused on Polish cultural heritage and history. Including elements of foreign students' cultures is still rather rare and it depends on the individual needs of individual teachers and educators.

We learn about Polish culture at school. For example, Polish songs, symbols, how different holidays are celebrated... Before Christmas at school we made several postcards for the fair. On Christmas Eve in class, the teacher said that we could prepare some of our dishes and show them to other people. Or tell something about how we celebrate holidays, e.g. Ramadan (...). (Amina, 12 years old, Chechnya) (Research: Formy...).

Cultural and identity issues of students with refugee background are sometimes raised by teachers during extracurricular Polish classes. As a result, the classes gain a more or less intercultural character. These types of activities are used to shape and strengthen the cultural awareness of students' identity. The approval is expressed and the specificity of the identity of Polish society is shown. The sense of being rooted in one's own

15 Marzanna is a doll made of various materials (straw, fabric, paper, etc.), which is set on fire and thrown into the river to say farewell to winter (old-time seasonal ritual).

16 Fat Thursday is a day related to the church calendar. This day, for many Polish people, it is the last day to eat lots of sugary food (in particular donuts) before Lent. 
culture is, as shown by scientific research, an important factor for integration (see i.a. Hovil, 2016). Presenting the complexity of the identity of Polish society is an important message which on the one hand shows its structure and richness, and on the other, informs students from migrant environments that there is a place for them in the new country of residence and school.

When organizing the process of teaching Polish, I take into account the culture of the country of origin of my students, I try to be aware of its impact on children's perception of reality. I try to make sure that the texts used during the classes do not contain hidden assumptions suggesting, for example, that all people living in Poland are Poles, they all celebrate the same Christian holidays, which is often the case in Polish textbooks. I avoid assumptions which are contrary to the cultural values and norms of foreign children's families. I believe that for activities carried out during classes, it is worth using content referring to the culture of students' origin, e.g. names used in their cultural circle, people in pictures wearing outfits appropriate to their cultural norms, situations close to the lifestyle of their families (...). (Teacher of Polish as a foreign language) (Research: Międzykulturowa...).

While waiting for international protection, many families with refugee background live in resident centers for foreigners located in the country. ${ }^{17}$ During their stay in the centers, foreigners have a possibility to receive medical care, psychological support and free Polish language lessons, etc. People who decide to reside in the centers as well as the ones outside them can participate in language classes. The author's observations show that classes in Polish as a foreign language taught in the centers are mainly attended by people who stay there during the period of waiting for international protection. For many of them, this is an additional opportunity to develop communication competences. These classes are only a drop in the ocean of needs, due to the number of hours in relation to the number of children living in the centers, as well as the way they are organized.

(...) There (in the center) I learned Polish a lot, I met a lot of people. (...) I attended Polish classes and later I stopped. Because subjects were repeated ... New people were coming (...). (Muslim, 13 years old, Ukraine) (Research: Przestrzeń...).

NGOs cooperating with schools (inside and outside of them) are important entities that support students from a migrant background in learning Polish. Depending on the nature of the project and the number and motivation of volunteers, the activities

17 In Poland, foreigners wait for international protection in centers located in the country (a total number: 9) or in rented apartments - they receive social benefits to pay the rent. The choice of place of residence depends on foreigners. Regardless of where they are, people waiting for international protection have the opportunity to participate in Polish language classes organized in the centers. 
of non-governmental organizations can provide significant support in language learning. Cooperation with volunteers is a special opportunity to develop communication skills as it enables learning of the Polish language in relation to the individual and current needs of students with a refugee background.

(...) I study Polish at the Center with a volunteer from the Foundation. We talk a lot during these lessons, I also learn new Polish words for example. We do tests, read various books, answer questions. For example, we read such a story about Warsaw and the legend of a she-wolf. During Saint Nicholas' Day classes, we learned about the legend of Santa and we colored Santa. We talked about his outfit (...). I learned what a synonym is, e.g. beautiful - pretty and what an antonym is. During summer holidays I also took part in a project - in additional classes" (Fariza, 12 years old, Chechnya) (Research: Formy....).

Sometimes the peers' help in learning a new language is invaluable. Their support often works like peer mentoring. Peer collaboration (see more i.a. Vickers, McCarthy \& Zammit, 2017) on the one hand enables learning Polish and on the other hand it allows building relationships between students - thanks to which students with refugee background become a part of the class community.

(...) They have been helping me to write for two years. A friend was sitting with me. She was helping me all the time. She told me what to write, read, because I couldn't read - still in the fourth grade ... She helped me, she did everything for me and I didn't know how to thank her ... I thanked her and it ended (...). (Muslim, 13 years old, Ukraine) (Research: Metody...).

The experiences of students with refugee backgrounds often indicate that communication is an important factor in integration with the class community. Language is a tool for everyday communication - expressing thoughts, needs, emotions (Stewart \& Logan, 2019, p. 82). In conflict situations, it allows us to defend our position and ourselves. Lack or poor language skills make it difficult for students with refugee background to participate in peer group activities (both spontaneous and organized).

- (...) It was difficult to get used to it at the beginning. New school, new friends. At first they didn't want to talk. But bit by bit, and now it's better.

- Why didn't they want to talk? [A.M-S.]

Maybe because I am from Ukraine... I did not hear anything offensive in my direction - that Poland is for Poles - as Nabi told me. They said so at the school he was in. They approached him and said so... (Ilia, 16 years old, Ukraine) (Research: Przestrzeń...).

Despite the educational compulsion which is inscribed in formal education, and adaptation difficulties occurring at the initial stages of education, and sometimes acts of discrimination; Polish school is a place often associated positively by students with 
refugee backgrounds. It is a space of many constructive experiences related to learning and peer relationships.

I go to this school because it is close to the center. We lived here and we came to this school - because it is close. And... cool. Because I like this school because here... I study and I have friends here. And it seems to me that I have the best class of all eighth graders (Gloria, 15 years old, Ukraine) (Research: Przestrzeń...).

The nature and results of the process of "entering" students with refugee backgrounds into a different culture depends on many aspects. The family environment usually does not play a leading role in the process of shaping the intercultural communication competence, which seems necessary in order to participate in the new culture. The family and parents of students with refugee backgrounds are replaced by an educational institution, professional educators and peers who act as "guides" in the new language and socio-cultural realities. What can be considered as important relates to: learning a new language intensively, finding out about the norms and values of a new society, getting to know the holidays, rites, customs and characteristic of the dominant culture of the new country. Thanks to school students, from the environment of forced migrants, learn new behaviour patterns, i.e. they learn how to behave in a given social situation. They begin to understand social behaviours that are characteristic of the culture of the new nation.

\section{Conclusion}

Migrations have accompanied people for centuries. Contemporary societies are becoming more and more culturally diverse due to the intensification of migratory movements. Despite the fact that Poland is a country with a relatively low degree of cultural diversity, significant transformations in the cultural landscape of Polish society has also been noticeable for years. Poland is inhabited by foreigners whose decision to change their place of residence was determined by a number of factors: from economic, through occupational, to those related to lack of safety in their own country. The culture of people with migration experience living in Poland is different from Polish culture. "Finding oneself" in a different reality requires a good knowledge of the new cultural environment. Priorities include knowledge of the official language of the host society and a dominant culture.

The process of assimilating the dominant culture of the new country of residence (acculturation) is complex, multifaceted and leads to changes in terms of the person's own cultural behaviour and identity. The more the culture of students with refugee background differs from the Polish one in terms of the system of values, interpersonal 
relations or the system of functioning, the more difficult it will be for them to adapt with the new cultural environment. Many behaviours of foreign children (it is similar with adults) can be recognized by the host society as strange, incomprehensible and/ or aggressive. They can arouse negative emotions and lead to conflicts. Fear of what is strange and unknown is something natural and may spontaneously trigger off a whole range of defensive reactions. Systematic learning of Polish in the intercultural context enables simultaneous learning of the Polish language and Polish culture. Despite the fact that education programs in Polish schools are still monocultural in nature, schools are the main environments in which students from migrant backgrounds develop intercultural communication competence.

From the perspective of the changing reality of a modern person, designing education that will provide knowledge and create conditions in which "cultural difference" will be practiced is extremely important. Cultural integration cannot be understood as a one-dimensional process that will require the indisputable adaptation of people with migration experience to the society and culture of the country of residence. Cultural integration is a challenge and a cultural task for both sides, and commitment is a manifestation of awareness and it involves taking responsibility for a shared world.

\section{References}

Acton, W.R., Walker de Felix, J. (1986). Acculturation and mind William R. Acton and Judith Walker de Felix. In J.M. Valdes (Ed.), Culture bound: bridging the cultural gap in language teaching. Cambridge: Cambridge University Press.

Aleksandrowicz-Pędich, L. (2005). Międzykulturowość na lekcjach języków obcych. Białystok: Wyd. Uniwersytetu w Białymstoku.

Bandura, E. (2007). Nauczyciel jako mediator kulturowy. Kraków: Wyd. Tertium.

Barzykowski, K., Grzymała-Moszczyńska, H., Dzida, D. et. al. (2013). One sq wśród nas. Wybrane zagadnienia diagnozy psychologicznej dzieci i młodzieży w kontekście wielokulturowości oraz wielojęzyczności. Warszawa: Ośrodek Rozwoju Edukacji.

Berry, J.W. (1998). Acculturation and health. In W.S.S. Kazarian \& D.R. Evans (Eds.), Cultura clinical psychology. Theory research and practice. New York: Oxford University Press.

Berry, J.W. (2003). Conceptual approaches to acculturation. In K.W. Chun, P.M. Organista, \& G. Marin (Eds.). Acculturation. Advances in theory, measurement, and applied research. Washington: APA.

Berry, J.W. (2006). Contexts of acculturation. In D.L. Sam \& J.W. Berry (Eds.), The Cambridge handbook of acculturation psychology. Cambrige. Cambrige University Press.

Gębal, P.E. (2010). Dydaktyka kultury polskiej w kształceniu językowym cudzoziemców. Podejście porównawcze. Kraków: Universitas.

Gębal, P.E. (2017). The Teacher and teaching Polish as a Second Language in the Contemporary Educational Reality. Culture. Society. Education, 1(11). 
Common European Framework of Reference for Languages: Learning, teaching, assessment (2011). Strasburg: Cambridge University Press. https://rm.coe.int/1680459f97 (accessing: 10.11.2019).

Grove, T.G. (2019). Niewerbalne elementy interakcji. In J. Steward (Ed.), Mosty zamiast murów. Podręcznik komunikacji interpersonalnej. Warszawa: PWN.

Gudykunst, W.B. \& Kim, Y.Y. (2019). Komunikowanie się z obcymi: spojrzenie na komunikację międzykulturową. In J. Steward (Ed.), Mosty zamiast murów. Podręcznik komunikacji interpersonalnej. Warszawa: PWN.

Hall, E.T. (1987). Bezgłośny język. Trans. E. Zimand, A. Skarbińska. Warszawa: Państwowy Instytut Wydawniczy.

Hall, E.T. (1997). Representation: Cultural Representations and Signifying Practices. London: Sage.

Hofstede, G., Hofstede, G.J., \& Minkov, M. (2010). Cultures and Organizations. Software of the mind. Intercultural Cooperation and Its Importance for Survival. New York: McGrawHill.

Hovil, L. (2016). Refugees, Conflict and the Search for Belonging. London: Palgrave Macmillan.

Informacja Szefa Urzędu do Spraw Cudzoziemców o stosowaniu w roku 2011 ustawy z dnia 13 czerwca 2003 r. o udzielaniu cudzoziemcom ochrony na terytorium Rzeczypospolitej Polskiej (Dz. U. z 2003 r. nr 128, poz z późn. zm.) w zakresie realizacji zobowiązań Rzeczypospolitej Polskiej wynikających z Konwencji Genewskiej dotyczącej statusu uchodźców oraz Protokołu Nowojorskiego dotyczącego statusu uchodźcy.

Kiklewicz, A. (2010). Tęcza nad potokiem... Kategorie lingwistyki komunikacyjnej, socjolingwistyki i hermeneutyki lingwistycznej w ujęciu systemowym. Łask: Oficyna Wydawnicza Leksem.

Maćkiewicz, J. (1999). Kategoryzacja a językowy obraz świata. In J. Bartmiński (Ed.), Językowy obraz świata. Lublin: Wyd. Uniwersytet Marii Curie-Skłodowskiej.

Mańczyk, A. (1982). Wspólnota językowa i jej obraz świata. Krytyczne uwagi do teorii językowej Leo Weisgerbera. Zielona Góra: Wyd. Wyższa Szkoła Pedagogiczna.

Magala, S. (2011). Kompetencje międzykulturowe. Warszawa: Wolters Kluwer Polska.

Młynarczuk-Sokołowska, A. (2017). Education of Foreign Children in Poland. Methodical Contexts. Culture and Education, 7, 168-181.

Młynarczuk-Sokołowska, A. (2015). Od Obcości do Inności. Międzykulturowa edukacja nieformalna na przykładzie polskich organizacji pozarządowych. Warszawa: Wydawnictwo Akademickie Żak.

Młynarczuk-Sokołowska, A. \& Szostak-Król, K. (2016). Zrozumieć Innego. Międzykulturowa kompetencja komunikacyjna w procesie uczenia się języka polskiego jako obcego. Białystok: Fundacja Dialog.

Młynarczuk-Sokołowska, A. \& Szostak-Król, K. (2019). Różnorodność i inkluzja w edukacji wybrane aspekty wspierania uczniów z doświadczeniem migracji. In I. Chrzanowska \& G. Szumski (Eds.), Edukacja włączająca w przedszkolu i szkole. Warszawa: Fundacja Rozwoju Systemu Edukacji.

Polok, K. (2006). Glottodydaktyczne elementy akulturacji. Od teorii do praktyki. Katowice: Oficyna Wydawnicza GWSH w Katowicach. 
Stewart, J. \& Logan, C. (2019). Komunikowanie się werbalne. In J. Steward (Ed.), Mosty zamiast murów. Podręcznik komunikacji interpersonalnej. Warszawa: PWN.

Szopski, M. (2015). Komunikowanie międzykulturowe. Warszawa: Wydawnictwa Szkolne i Pedagogiczne.

Vickers, M., McCarthy, F., \& Zammit K. (2017). Peer mentoring and intercultural understanding: Support for refugee-background and immigrant students beginning university study. International Journal of Intercultural Relations, 60, 198-209.

Whorf, B.L. (2011). Language, Thought, and Reality: Selected Writings of Benjamin Lee Whorf. Martino Fine Books.

Wysocka, E. (2003). Acculturation. In T. Pilch (Ed.), Encyklopedia pedagogiczna XXI wieku. T. I, Warszawa: Wydawnictwo Akademickie Żak.

Zawadzka, E. (2000). Glottodydaktyczne aspekty interkulturowości. In Z. Kielar, T.P. Lukszyn, \& T. Namowicz (Eds.), Problemy komunikacji międzykulturowej: lingwistyka-translaktyka - glottodydaktyka. Warszawa: Wyd. Graf-Punkt.

\section{Legal acts}

Konstytucja Rzeczypospolitej Polskiej z dnia 2 kwietnia 1997 r. Dz.U. 1997 nr 78 poz. 483.

Ustawa z dnia 14 grudnia 2016 roku, Prawo oświatowe (Dz.U. z 2019 r. poz. 1148, 1078, 1287, $1680,1681,1818,2197$ i 2248$).$

Konwencja dotycząca statusu uchodźców sporządzona w Genewie dnia 28 lipca 1951 r. (Dz.U. z 1991 r. nr 119, poz. 515 i 517).

Rozporządzeniu Ministra Edukacji Narodowej z dnia 23 sierpnia 2017 r. w sprawie kształcenia osób niebędących obywatelami polskimi oraz osób będących obywatelami polskimi, które pobierały naukę w szkołach funkcjonujących w systemach oświaty innych państw (Dz.U. z 2017 r., poz. 1655).

Ustawa o udzielaniu cudzoziemcom ochrony na terytorium Rzeczpospolitej Polskiej z dnia 13 czerwca 2003 r. (Dz.U. z 2003 r. nr 128, poz. 1176 z późn. zm.).

\section{Empirical material}

Contents of narrative interviews conducted in 2019 as a part of the study Przestrzeń szkoły w percepcji uczniów z doświadczeniem migracji uchodźczej [Space of School in the Perception of Students with Refugee Background] among students at the age of 10-16. Research implementer: Anna Młynarczuk-Sokołowska.

Contents of free-form interviews conducted in 2017 as a part of the study Doświadczenia cudzoziemców dotyczqce akulturacji w Polsce [Experiences of Foreigners connected with Acculturation in Poland]. Research implementer: Anna Młynarczuk-Sokołowska.

Contents of casual interviews conducted in 2014 as a part of the study Formy i metody uczenia się języka polskiego dzieci cudzoziemskich [Forms and Methods of Learning Polish by Foreign Children] among foreign students at the age of 7-12. Research implementers: Anna Młynarczuk-Sokołowska, Katarzyna Szostak-Król. 
Contents of casual interviews conducted in 2014 as a part of the study Międzykulturowa kompetencja komunikacyjna w nauczaniujęzyka obcego dzieci w wieku 7-12 lat [Intercultural Communication Competence in Teaching a Foreign Language to Children aged 7-12] among teachers of Polish as a foreign language in primary schools. Research implementers: Anna Młynarczuk-Sokołowska, Katarzyna Szostak-Król. 